\title{
THE COGNITIVE TRANSITION IN MEXICO: ECONOMIC GEOGRAPHY AND LOCAL GOVERNANCE IMPACTS
}

\author{
David Mayer-Foulkes*
}

\section{Resumen}

Este artículo muestra que la dinámica de la capacidad cognitiva interactúa con indicadores individuales y locales de bienestar macroeconómico, bienes públicos y bienes privados suministrados, a través de 141 localidades en México. La relación de estos diversos bienes con la inequidad se compara cuantitativamente mediante la descomposición del índice de concentración. El conjunto de características individuales tales como la capacidad cognitiva paterno y materno, si la madre trabaja, la escolaridad del padre y riqueza del hogar, y el conjunto de características, entre ellas la actividad económica local, la política pública local y los indicadores locales de marginación, cada uno tiene importantes conexiones con la formación de la capacidad cognitiva. Vivir en una localidad rural se asocia a una cuarta parte de las desigualdades en la capacidad cognitiva. Esto es coherente con un modelo de desarrollo humano y el crecimiento económico que presenta agregados macroeconómicos a través de los canales que la geografía económica y la gobernanza local pueden dar lugar a la estratificación y la divergencia en los indicadores de bienestar. Hay una transición a largo plazo hacia niveles más altos de habilidad cognitiva que se llevará varias generaciones para converger a la tasa actual.

Palabras clave: capacidad cognitiva, transición cognitiva, geografía económica, gobernanza local, América Latina, México

Clasificación JEL: R11, R58

* Centro de Investigación y Docencia Económicas, México, D. F. e-mail: <david.mayer@cide.edu>. 
DAVID MAYer-Foulkes

\section{Abstract}

This article shows that cognitive ability dynamics interact with both individual and local indicators of macroeconomic wellbeing, publicly provided goods and private goods, through 141 localities in Mexico. The link of these various goods with inequity is compared quantitatively using the concentration index decomposition. The set of individual characteristics including paternal and maternal cognitive ability, whether mother works, father's schooling and household wealth, and the set of local characteristics including local economic activity, local public policy and local marginalization indicators, each have significant connections with the formation of cognitive ability. Living in a rural locality is associated with one fourth of inequities in cognitive ability. This is consistent with a model of human development and economic growth exhibiting aggregate macroeconomic channels through which economic geography and local governance can lead to stratification and divergence in welfare indicators. There is a long-term transition towards higher levels of cognitive ability that will take several generations to converge at the current rate.

Keywords: cognitive ability, cognitive transition, economic geography, local governance, Latin America, Mexico

JEL Classification: R11, R58

\section{Introduction}

What are the structural forces that create and perpetuate extreme inequalities in human development? This urgent question continues to challenge policy makers concerned with finding the best ways of overcoming poverty and enhancing social welfare.

What roles do supply and demand play in the transmission of education and health? This question leads to considering the role of economic geography. On the one hand the demand for human capital is rooted in the local economy, itself subject to the forces of economic geography. On the other hand the supply of human capital depends on household assets and on the local provision of human capital goods -sanitation, schools, clinics, hospitals, universities- the first a byproduct of the local economy and the second subject to the local demand for its services. Families seeking to endow 
their offspring with human capital thus take their investment decisions based on their individual resources and on local incentives and costs. Alternatively, if local conditions are bad enough, migration may become the best option.

The importance of geographical forces in the process of development has been clear since Harris and Todaro's (1970) model on rural-urban migration. In fact, socioeconomic reality presents itself as a huge, complex, socio-geographic mosaic of heterogeneous regions, localities and neighborhoods that feature within themselves various degrees of homogeneity. This sociogeographic mosaic consists of favelas, rich or middle class neighborhoods, industrial cities, rural villages and so on. Seeking to explain this reality, a whole literature on economic geography has emerged. Following Baldwin et al. (2003) review of the state of the art in this literature, such conditions include familiar geographical effects typically working through agglomeration, such as market access effects due to proximity and industrial concentration, vertical linkages, economic specialization, cost of living effects, congestion, local technological and other knowledge externalities and decreasing returns to agriculture. They also include governance effects working through the impact of public policies and through levels of publicly provided goods.

In a related article, Mayer-Foulkes (2008a) constructs a model of economic growth and human development, based on endogenous technological change that incorporates considerations of economic geography. The model shows that even in the presence of perfect capital, goods and labor markets, economic geography and local governance effects can lead to stratification and divergence. Human capital productivity, human capital production costs and the incentives for human capital accumulation can each be affected by local conditions. This article shows that both individual and local variables proxying for effects originating in economic geography and governance are linked with early child development in Mexico, specifically with cognitive ability and height for age.

Early Child Development (ECD) is the foundation for life-long capabilities in health, education and income. In developed countries, ECD is identified as a crucial stage of investment in human capital formation, with especially high returns (Heckman and Carneiro, 2003). Similarly, childhood health is placed at the origin of the "gradient" of adult health along income (Case, Fertig, and Paxson, 2003; Case, Lubotsky and Paxson, 2002). Thus, inequities in ECD form the basis of the intergenerational transmission of inequality in human capital. 
In the last decade, health has joined education in a unified conception of human capital. Nobel Prize winning historical studies by Fogel and Wimmer (1992) and Fogel (1994) find that a third or even one half of the economic growth in England over the last 200 years is due to improvements in nutrition and health. Arora (2001) finds comparable results for seven advanced countries using 100 -to 125-year time series of diverse health indicators. This line of research has concluded that the synergism between technological and physiological improvements has produced a rapid, culturally transmitted form of human evolution that is biological but not genetic. This long-term process, which continues in both rich and developing nations, is called technophysio evolution by Fogel (2002).

This process has involved momentous secular rises in stature, weight, life expectancy, education. ${ }^{1}$ Now, cognitive ability represents at the same time a measure of children's health, their potential for education, and one of the kernels of early child development. Thus, it is to be expected that cognitive ability is also subject to long-term, secular rises. We show below evidence that such a transition is indeed occurring in Mexico, and that its determinants include the forces of economic geography and local governance. Recent studies by Mayer Foulkes et al. (2008) and MayerFoulkes and Serván-Mori (2008) also show that socioeconomic status and public policies have impacts on the formation of cognitive capacity in Mexico.

Average scores on intelligence tests are known to have been rising consistently ever since the tests were developed, at about three IQ points per decade. It has been necessary to renormalize tests periodically to maintain a mean score of 100. Although it remains controversial whether intelligence itself has risen, and while it might be expected that the greatest score gains are related to such school content as vocabulary, arithmetic or general information, just the opposite is the case. The largest score increases appear on culture reduced highly general intelligence factor loaded (g-loaded) tests such as Raven's Progressive Matrices, the kind of test applied in the data sources used for this article. ${ }^{2}$

1 Average stature rose from 164 to $181 \mathrm{~cm}$ in Holland between 1860 and 2002 and from 161 to $173 \mathrm{~cm}$ in France and Norway between 1705 and 1975. Average weight rose from 46 to $73 \mathrm{~kg}$ in Norway and France, 1705 to 1975. Life expectancy rose from 41 to 78 years in England between 1841 and 1998; and from 29 to 60 years in India between 1930 and 1990 (Fogel, 2002; Cervellati, Matteo and Uwe Sunde, 2005).

2 See Neisser (1997) for a review and discussion on the secular rise in IQ scores. 
In Latin America and the Caribbean (LAC), and in particular in Mexico, problems in human capital investment are strong enough that there may be a long-term human development trap (Mayer-Foulkes, 2008b) 3 in which low ECD makes schooling less productive, and schooling itself is not accessible to much of the population. Even so, it is not clear what the main problems generating persistent deficits in human capital accumulation are. Poverty and inequality did not decline in Latin America during the 1990s in spite of improvements at the macroeconomic level (Londoño and Székely, 2000). Here it is suggested that the externalities involved in economic geography and problems in the provision of public goods generate inequities in human capital investment.

While many authors stress the importance of access to social and political rights for reducing inequality in LAC (e.g. Justino, Litchfield and Whitehead, 2003), and in spite of the importance of the dynamics generated by economic geography, as witnessed by the growth of cities, the extent of migration, and the polarization that tends to occur between regions, there are few studies on the impact of economic geography on human development.

The remainder of the article is organized as follows. Section 2 contains the econometric analysis, including description of methods, data and results. The next two sections discuss and conclude. Mayer-Foulkes (2008a) contains a discussion on the long-term relation between human development and economic growth and the economic geography of human capital investment, a discussion on endogenous technological change and economic growth, and a theoretical model of stratified and divergent regional economic growth and human development which we do not repeat here.

\section{Econometric analysis}

The interactions of individual and local determinants of human capital are highly complex. To begin with, in the household there are both genetically and economically inherited factors such as ability and wealth that actindependently of acquired human capital assets, such as education. Cognitive ability is both inherited and acquired, and acts upon child formation through a whole variety of channels, including assortative mating, achieved income, effectiveness at

3 This article presents a human development trap model and supporting evidence for its existence in Mexico. It also includes a literature review on ECD. 
educating offspring and combining available resources. Disentangling these causal links has high data and methodological requirements, e.g. Behrman and Rosenzweig (2002), Black and Salvanes (2005), Plug (2004), who deal with the problems of unobserved ability -less of a problem here since cognitive ability is often used as indicator for this; inherited versus acquired assets; intergenerational correlation of endowments; and assortative mating. Yet besides this, as the household navigates its way through the complex process of caring for and bringing up children, household members make complex decisions based on the availability of goods and the returns of present and future assets, that in turn depend on the local context and therefore are subject to a regional impact. Thus, it is not only a matter of inherited versus acquired cognitive ability, and of the direct and indirect impacts of parental assets, but of the environment provided by the economic geography and local public goods context for the process of child formation.

When we analyze the formation of cognitive ability, a substantial portion of genetic endowment is taken care of by the presence of parental cognitive ability indicators, whose coefficients are not our main concern. The other individual variables cover several additional dimensions of wealth and human capital, inherited or acquired. Local indicators include sets on local government and local coverage of public programs; local welfare, economic activity and population, and a rural indicator. Since public programs tend to be targeted, they can be correlated with other local indicators (Rosenzweig and Wolpin, 1986). It follows that nonlinearities may be involved in the coefficients of these various variables. Thus care has to be taken in interpreting the signs they obtain.

The cross-section format we use and the availability of variables does not allow inferring causality, much precision in the coefficient estimates. However, this is not the aim of the study. What we do observe is that local and regional variables have a significant impact on the determination of inequities in cognitive ability -even in the presence household asset information. This is enough to support a model of human capital accumulation that involves local economic geography and public governance impacts -and that is therefore beyond the reach of simplistic market policies.

\section{(a) The analysis}

We analyze cognitive ability test results and using microeconomic household data from the Mexican Family Life Survey (MxFLS) conducted in 2002. This survey includes demographic, socioeconomic and anthropometric data 
on individuals, households and communities from approximately 8400 households, obtained from about 38 thousand interviews distributed over 141 localities in Mexico. The survey is representative at the national, regional and rural-urban levels (Rubalcava and Teruel, 2004).

These are analyzed separately for age groups 5 to 12 and 13 to 18 . The analysis consists of first, a regression showing that there is a quantitatively and statistically significant dependence of cognitive ability on local and regional variables, after controlling for individual household variables. The regional variables represent regional governance and economic geography. The results show that these are indeed significantly associated with individual wellbeing.

Second, using the previous regressions, the Concentration Index (CI) decomposition (Wagstaff and van Doorslaer, 2000) is estimated along a socioeconomic status indicator defined below. This provides a measure of the correlation of these individual and local indicators with the intergenerational transmission of cognitive inequities.

In different runs of these regressions involving selective presence of the local and regional indicators, whose results are significant, the coefficients and significances of individual indicators remain fairly robust. This supports the view that the local and regional indicators are missing variables that are associated with cognitive ability.

Third, I regress daughter's and son's cognitive ability against their mother's and father's against mother's, and show that there is a longterm intergenerational transition in cognitive ability that will take several generations to converge at the current rate.

\section{(b) The data}

As mentioned above, the data comes from MxFLS 2002. Children ages 5 to 12 received one kind of cognitive abilities, while children 13 and older and adults received another. Therefore the estimates are performed for children in two age groups, 5 to 12 and 13 to 18. The independent variables are child's gender and fixed age effects; paternal and maternal cognitive abilities, height for age z-score and schooling; whether Mother works; log household expenditure; and access to private and public services. Access to private services is the first polychoric principal components factor ${ }^{4}$ for housing

4 McKenzie, D. (2004) establishes the relevance of principal component factors as indicators of composite goods such as these, and Kolenikov (2004) stresses the importance of taking into account the discrete nature of some of the data. 
characteristics that can be acquired privately, specifically type of floor, cleanliness, ventilation, and bathroom. Similarly, access to public services is the first polychoric principal components factor for housing characteristics that depend on publically provided goods, specifically electricity, and variables describing type of water source and drainage. Socioeconomic status, used for the concentration index decomposition, was defined as the first polychoric principal component of these two sets of variables together with log household expenditure.

The local variables used were, first, number of clinics, primary schools, middle schools and high schools in the locality; rural dummy and log total population, and second, a set of local indicators constructed again as first polychoric principal components. These are the negative of a local poverty indicator, based on log number of poor households, log number of poor persons, ratio of poor to rich population and quality of infrastructure; a local public policy indicator based on how many people benefit from Progresa, government credits, temporary employment programs, the national day laborer program (Nacional de Jornaleros), Procampo, VIVAH (housing for marginal populations), "Crédito a la Palabra" (agricultural credit program), and several other government programs ("Contigo Manos a la Obra", "Fondo Regional Indígena", "Fondo de Coinversión Social", "Desarrollo Productivo de la Mujer", "Servicio Social Comunitario", and "other" social programs.); $;^{5}$ a local marginalization indicator based on quality of street materials, proportion of households with telephones, electricity and water; a local economic activity indicator base on indicators on economic activity related to agriculture, livestock, industry, manufacture, electricity gas and water, and "other"; a local government improvement indicator based on perception of improvement of government and educational services. The sign of all principal components is chosen to represent a good, e.g. wealth rather than poverty, industry rather than agriculture or "other", presence and improvement of government programs and services rather than the opposite. Table 1 shows descriptive statistics for the main indicators.

“Contigo Manos a la Obra" ("Let's Work"), “Fondo Regional Indígena” (Regional Indigenous Fund), "Fondo de Coinversión Social" (Social Joint Investment Fund), "Desarrollo Productivo de la Mujer" (Women's Productive Development), "Servicio Social Comunitario" (Community Social Service), and "Other" social programs. 
The Cognitive transition in Mexico: ECONOMIC GEOGRAPHY AND LOCAL GOVERNANCE IMPACTS

Table 1

Descriptive Statistics: Mean and Standar Deviation

\begin{tabular}{|c|c|c|c|}
\hline Variable & $\begin{array}{c}\text { Mean } \\
\text { and } \\
\text { Standard } \\
\text { Deviation }\end{array}$ & Variable & $\begin{array}{c}\text { Mean } \\
\text { and } \\
\text { Standard } \\
\text { Deviation }\end{array}$ \\
\hline Children's Cognitive Ability & $\begin{array}{c}0.6 \\
(0.22)\end{array}$ & $\begin{array}{l}\text { Beneficiaries of "Trabajo } \\
\text { Temporal" }\end{array}$ & $\begin{array}{l}0.55 \\
(0.5)\end{array}$ \\
\hline Father's Cognitive Ability & $\begin{array}{c}0.51 \\
(0.24)\end{array}$ & $\begin{array}{l}\text { Beneficiaries of } \\
\text { "Procampo" }\end{array}$ & $\begin{array}{c}0.73 \\
(0.44)\end{array}$ \\
\hline Mother's Cognitive Ability & $\begin{array}{c}0.47 \\
(0.24)\end{array}$ & $\begin{array}{l}\text { Type of Material Covering } \\
\text { Roads and Streets }\end{array}$ & $\begin{array}{c}2.51 \\
(0.79)\end{array}$ \\
\hline $\begin{array}{l}\text { Father's Height for Age } \\
\text { z-score }\end{array}$ & $\begin{array}{l}-4.37 \\
(3.21)\end{array}$ & $\begin{array}{l}\text { Percent Households with } \\
\text { Telephone }\end{array}$ & $\begin{array}{c}2.38 \\
(1.38)\end{array}$ \\
\hline $\begin{array}{l}\text { Mother's Height for Age } \\
\text { z-score }\end{array}$ & $\begin{array}{l}-2.62 \\
(3.5)\end{array}$ & $\begin{array}{l}\text { Percent Households with } \\
\text { Electricity }\end{array}$ & $\begin{array}{c}449.22 \\
(6396.74)\end{array}$ \\
\hline Father's Schooling & $\begin{array}{l}7.82 \\
(4.28)\end{array}$ & $\begin{array}{l}\text { Percent Households with } \\
\text { Piped Water }\end{array}$ & $\begin{array}{c}84.88 \\
(25.36)\end{array}$ \\
\hline Mother's Schooling & $\begin{array}{c}6.97 \\
(3.51)\end{array}$ & $\begin{array}{l}\text { Economic Activity: } \\
\text { Agriculture }\end{array}$ & $\begin{array}{c}0.74 \\
(0.44)\end{array}$ \\
\hline Mother Works & $\begin{array}{c}0.3 \\
(0.46)\end{array}$ & $\begin{array}{l}\text { Economic Activity: Cattle } \\
\text { Ranching }\end{array}$ & $\begin{array}{c}0.63 \\
(0.48)\end{array}$ \\
\hline Log Household Expenditure & $\begin{array}{l}10.52 \\
(0.81)\end{array}$ & $\begin{array}{l}\text { Economic Activity: } \\
\text { Manufacturing Industry }\end{array}$ & $\begin{array}{c}0.28 \\
(0.45)\end{array}$ \\
\hline Access to Private Services & $\begin{array}{l}-0.01 \\
(0.41)\end{array}$ & $\begin{array}{l}\text { Economic Activity: } \\
\text { Electricity, Gas, Water }\end{array}$ & $\begin{array}{c}0.11 \\
(0.32)\end{array}$ \\
\hline Access to Public Services & $\begin{array}{r}-0.05 \\
(1.2)\end{array}$ & Economic Activity: Other & $\begin{array}{c}0.19 \\
(0.39)\end{array}$ \\
\hline Number of Clinics & $\begin{array}{c}0.76 \\
(2.31)\end{array}$ & $\begin{array}{l}\text { Improved Quality of } \\
\text { Government Services }\end{array}$ & $\begin{array}{c}1.44 \\
(3.08)\end{array}$ \\
\hline Number of Primary Schools & $\begin{array}{c}37 \\
(86.82)\end{array}$ & $\begin{array}{l}\text { Change in Quality of } \\
\text { Education }\end{array}$ & $\begin{array}{l}1.25 \\
(1.2)\end{array}$ \\
\hline Number of Middle Schools & $\begin{array}{c}18.86 \\
(47.52)\end{array}$ & $\begin{array}{l}\text { Negative of Local Poverty } \\
\text { Indicator }\end{array}$ & $\begin{array}{l}-0.03 \\
(1.27)\end{array}$ \\
\hline Number of High Schools & $\begin{array}{c}12.42 \\
(35.18)\end{array}$ & $\begin{array}{l}\text { Local Public Policy } \\
\text { Indicator }\end{array}$ & $\begin{array}{c}0 \\
(1.57)\end{array}$ \\
\hline Beneficiaries of "Progresa" & $\begin{array}{l}0.79 \\
(0.4)\end{array}$ & $\begin{array}{l}\text { Negative of Local } \\
\text { Marginalization }\end{array}$ & $\begin{array}{l}-0.03 \\
(0.95)\end{array}$ \\
\hline Rural & $\begin{array}{l}0.55 \\
(0.5)\end{array}$ & $\begin{array}{l}\text { Local Economic Activity } \\
\text { Indicator }\end{array}$ & $\begin{array}{l}-0.02 \\
(0.92)\end{array}$ \\
\hline Log Total Population & $\begin{array}{c}8.27 \\
(3.72)\end{array}$ & $\begin{array}{l}\text { Local Government } \\
\text { Improvement Indicator }\end{array}$ & $\begin{array}{c}-0.01 \\
(0.8)\end{array}$ \\
\hline
\end{tabular}

Standar deviation in parenthesis.

Source: own elaboration. 
DAVID MAYer-Foulkes

(c) Results

The CI and decomposition used follow the theoretical and computational methods in Wagstaff et al. (2008). The concentration index for cognitive ability for the two age groups is shown in Table 2.

Table 2

Concentration Index

\begin{tabular}{ccc}
\hline Variable & Ages 5 to 12 & Ages 13 to 18 \\
\hline Cognitive ability & 0.031 & 0.035 \\
& $(6.1)$ & $(4.5)$ \\
\hline t-statistics in parenthesis & & \\
\hline Source: own elaboration. & &
\end{tabular}

\section{(i) Regression results}

Five CI decompositions were implemented for each age group 5 to 12 and 13 to 18. All of the independent variables, being parental and regional indicators, are exogenous to errors in the three ECD indicators. However, error correlation is expected within geographical regions. Hence locally clustered robust estimates are used. This also eliminates biases that may be associated with the use of regional contextual variables, which could be correlated with the individual error structure.

The set of independent variables is a fairly complete set of individual and regional economic indicators that are adequate for exploring the economic component of the formation of cognitive ability. The results are shown in Tables 3.1 for age group 5 to 12 and in Table 3.2 for ages 13 to 18. In each case Regression 1 including only parental cognitive abilities and child gender and fixed age effects is estimated for reference. It shows the magnitude of direct and indirect effects of parental cognitive abilities on the formation of children's cognitive abilities. Regression 2 includes in addition to these basic variables, father's and mother's height for age z-score, schooling, whether mother works, log household expenditure, and access to private and to public services. Regression 3 includes in addition number of clinics, primary schools, middle schools and high schools in the locality, that is, local facilities for investing in human capital. Regression 4 completes the set of local indicators by adding rural dummy and log total local population, the negative of local poverty indicator, and the local public policy, marginalization, economic activity, and government improvement 
indicators mentioned above. Regression 5 replaces all local indicators with local fixed effects. ${ }^{6}$

The sequence of regression successively accounts for a fuller set of individual and local variables. Correspondingly, the coefficients for father's and mother's cognitive ability, which are significant at the $1 \%$ level in every case, diminish by $17 \%$ and $11.5 \%$ for fathers and mothers of the 5 to 12 age group and by $26.5 \%$ and $12 \%$ respectively for the 13 to 18 age group. This represents an approximate idea of the indirect effects of parental cognitive ability in obtaining the individual and local indicators included in the regressions for representing inputs of their children's cognitive ability. The results suggest quite plausibly that inputs associated with maternal cognitive ability are not sufficiently represented.

The main significant individual indicators are whether mother works, which is negatively associated with cognitive ability in the 5 to 12 age group, and access to private services, a private wealth quality of life indicator that is positive and significant especially in the case of the older age group.

As for the local indicators, numbers of clinics and schools are not robustly significant. Rural is significant with a negative sign for both age groups. The local economicactivity indicator pointing towards industry and manufacturing is significant and negative for ages 5 to 12, probably in association with urban hardship. For the older age group the local public policy indicator obtains an unexpected significant negative coefficient, perhaps because many of the policies involved operate in rural areas, while the negative of marginalization obtains a significant positive sign. In Regression 5, fixed effects for the localities are jointly highly significant. In this final regression, father's schooling and access to private services are less significant, showing that they are proxying for other local effects.

\section{(ii) Concentration index decomposition results}

The ranking variable along which concentration is measured is individual socioeconomic status, defined as the first polychoric principal component of a set of indicators of access to public and private goods, together with log household expenditure, as mentioned above. By projecting on this ranking variable, the $\mathrm{CI}$ decomposition provides a measure of the impact of each dependent variable's equity on cognitive ability equity.

6 Once calculated, the significance of the fixed effects is estimated by including the sum of the predicted fixed effects in a separate regression. 
Tabla 3.1

Decomposition regressions for children's cognitive ability. Ages 5 to 12

\begin{tabular}{|c|c|c|c|c|c|}
\hline Variable & 1 & 2 & 3 & 4 & 5 \\
\hline Gender & $\begin{array}{c}0.001 \\
(0.959)\end{array}$ & $\begin{array}{c}0.001 \\
(0.912)\end{array}$ & $\begin{array}{c}0.001 \\
(0.943)\end{array}$ & $\begin{array}{c}0.001 \\
(0.957)\end{array}$ & $\begin{array}{c}0.001 \\
(0.943)\end{array}$ \\
\hline $\begin{array}{l}\text { Father's Cognitive } \\
\text { Ability }\end{array}$ & $\begin{array}{l}0.141 \\
(0)^{* * * *}\end{array}$ & $\begin{array}{l}0.127 \\
(0)^{* * *}\end{array}$ & $\begin{array}{l}0.126 \\
(0)^{* * *}\end{array}$ & $\begin{array}{l}0.124 \\
(0)^{* * *}\end{array}$ & $\begin{array}{c}0.117 \\
(0.001)^{* * * *}\end{array}$ \\
\hline $\begin{array}{l}\text { Mother's Cognitive } \\
\text { Ability }\end{array}$ & $\begin{array}{l}0.226 \\
(0)^{* * *}\end{array}$ & $\begin{array}{l}0.215 \\
(0)^{* * * *}\end{array}$ & $\begin{array}{l}0.214 \\
(0)^{* * *}\end{array}$ & $\begin{array}{l}0.209 \\
(0)^{* * *}\end{array}$ & $\begin{array}{c}0.2 \\
(0)^{* * * *}\end{array}$ \\
\hline $\begin{array}{l}\text { Father's Height for } \\
\text { Age z-score }\end{array}$ & & $\begin{array}{c}0 \\
(0.965)\end{array}$ & $\begin{array}{c}0 \\
(0.985)\end{array}$ & $\begin{array}{c}0 \\
(0.932)\end{array}$ & $\begin{array}{c}0 \\
(0.957)\end{array}$ \\
\hline $\begin{array}{l}\text { Mother's Height for } \\
\text { Age z-score }\end{array}$ & & $\begin{array}{l}-0.002 \\
(0.273)\end{array}$ & $\begin{array}{l}-0.002 \\
(0.232)\end{array}$ & $\begin{array}{l}-0.002 \\
(0.236)\end{array}$ & $\begin{array}{l}-0.002 \\
(0.159)\end{array}$ \\
\hline Father's Schooling & & $\begin{array}{c}0 \\
(0.824)\end{array}$ & $\begin{array}{c}0 \\
(0.885)\end{array}$ & $\begin{array}{c}0 \\
(0.996)\end{array}$ & $\begin{array}{c}0 \\
(0.962)\end{array}$ \\
\hline Mother's Schooling & & $\begin{array}{c}0.001 \\
(0.557)\end{array}$ & $\begin{array}{c}0.001 \\
(0.585)\end{array}$ & $\begin{array}{c}0.001 \\
(0.733)\end{array}$ & $\begin{array}{c}0.001 \\
(0.793)\end{array}$ \\
\hline Mother Works & & $\begin{array}{c}-0.023 \\
(0.002)^{* * *}\end{array}$ & $\begin{array}{c}-0.024 \\
(0.002)^{* * *}\end{array}$ & $\begin{array}{c}-0.024 \\
(0.003)^{* * * *}\end{array}$ & $\begin{array}{c}-0.026 \\
(0.001)^{* * * *}\end{array}$ \\
\hline $\begin{array}{l}\text { Log Household } \\
\text { Expenditure }\end{array}$ & & $\begin{array}{c}0.004 \\
(0.666)\end{array}$ & $\begin{array}{c}0.004 \\
(0.701)\end{array}$ & $\begin{array}{c}0.001 \\
(0.923)\end{array}$ & $\begin{array}{c}0.007 \\
(0.516)\end{array}$ \\
\hline $\begin{array}{l}\text { Access to Private } \\
\text { Services }\end{array}$ & & $\begin{array}{c}0.022 \\
(0.042)^{* *}\end{array}$ & $\begin{array}{c}0.022 \\
(0.025)^{* *}\end{array}$ & $\begin{array}{c}0.02 \\
(0.088)^{*}\end{array}$ & $\begin{array}{c}0.016 \\
(0.156)\end{array}$ \\
\hline $\begin{array}{l}\text { Access to Public } \\
\text { Services }\end{array}$ & & $\begin{array}{c}0.009 \\
(0.071)^{*}\end{array}$ & $\begin{array}{c}0.008 \\
(0.088)^{*}\end{array}$ & $\begin{array}{l}0.007 \\
(0.14)\end{array}$ & $\begin{array}{c}0.008 \\
(0.213)\end{array}$ \\
\hline Number of Clinics & & & $\begin{array}{c}0.001 \\
(0.889)\end{array}$ & $\begin{array}{c}0.002 \\
(0.837)\end{array}$ & \\
\hline $\begin{array}{l}\text { Number of Primary } \\
\text { Schools }\end{array}$ & & & $\begin{array}{c}0.005 \\
(0.093)^{*}\end{array}$ & $\begin{array}{l}0.002 \\
(0.62)\end{array}$ & \\
\hline $\begin{array}{l}\text { Number of Middle } \\
\text { Schools }\end{array}$ & & & $\begin{array}{l}-0.006 \\
(0.375)\end{array}$ & $\begin{array}{c}-0.004 \\
(0.7)\end{array}$ & \\
\hline $\begin{array}{l}\text { Number of High } \\
\text { Schools }\end{array}$ & & & $\begin{array}{l}0.003 \\
(0.55)\end{array}$ & $\begin{array}{c}0 \\
(0.964)\end{array}$ & \\
\hline Rural & & & & $\begin{array}{l}-0.031 \\
(0.02)^{* *}\end{array}$ & \\
\hline Log Total Population & & & & $\begin{array}{c}0.001 \\
(0.767)\end{array}$ & \\
\hline $\begin{array}{l}\text { Negative of Local } \\
\text { Poverty Indicator }\end{array}$ & & & & $\begin{array}{c}0.005 \\
(0.335)\end{array}$ & \\
\hline $\begin{array}{l}\text { Local Public Policy } \\
\text { Indicator }\end{array}$ & & & & $\begin{array}{c}0 \\
(0.975)\end{array}$ & \\
\hline $\begin{array}{l}\text { Negative of Local } \\
\text { Marginalization }\end{array}$ & & & & $\begin{array}{c}0.001 \\
(0.883)\end{array}$ & \\
\hline $\begin{array}{l}\text { Local Economic } \\
\text { Activity Indicator }\end{array}$ & & & & $\begin{array}{l}-0.013 \\
(0.03)^{* *}\end{array}$ & \\
\hline $\begin{array}{l}\text { Local Government } \\
\text { Improvement } \\
\text { Indicator }\end{array}$ & & & & $\begin{array}{l}-0.006 \\
(0.398)\end{array}$ & \\
\hline $\begin{array}{l}\text { Sum of Local Fixed } \\
\text { Effects }\end{array}$ & & & & & $\begin{array}{c}1 \\
(0)^{* * *}\end{array}$ \\
\hline \multicolumn{6}{|l|}{$\begin{array}{l}\text { Age Fixed Effects not } \\
\text { Reported }\end{array}$} \\
\hline Constant & $\begin{array}{l}0.305 \\
(0)^{* * *}\end{array}$ & $\begin{array}{c}0.266 \\
(0.003)^{* * *}\end{array}$ & $\begin{array}{c}0.264 \\
(0.004)^{* * *}\end{array}$ & $\begin{array}{c}0.317 \\
(0.001)^{* * *}\end{array}$ & $\begin{array}{c}0.322 \\
(0.007)^{* * * *}\end{array}$ \\
\hline Observations & 2398 & 2398 & 2398 & 2398 & 2398 \\
\hline F & 70.62 & 43.28 & 40 & 36.8 & 30.8 \\
\hline Prob $>F$ & 0 & 0 & 0 & 0 & 0 \\
\hline$R$ squared & 0.295 & 0.303 & 0.304 & 0.31 & 0.356 \\
\hline
\end{tabular}

$\mathrm{p}$ values in parenthesis; significance: ${ }^{*} 0.1,{ }^{* *} 0.05,{ }^{* * *} 0.01$

Source: own elaboration. 
The Cognitive transition in Mexico: ECONOMIC GEOGRAPHY AND LOCAL GOVERNANCE IMPACTS

Tabla 3.2

Decomposition regressions for children's cognitive ability. Ages 13 to 18

\begin{tabular}{|c|c|c|c|c|c|}
\hline Variable & 1 & 2 & 3 & 4 & 5 \\
\hline Gender & $\begin{array}{l}-0.001 \\
(0.944)\end{array}$ & $\begin{array}{l}-0.002 \\
(0.87)\end{array}$ & $\begin{array}{c}-0.003 \\
(0.803)\end{array}$ & $\begin{array}{l}-0.002 \\
(0.886)\end{array}$ & $\begin{array}{l}-0.007 \\
(0.631)\end{array}$ \\
\hline $\begin{array}{l}\text { Father>s Cognitive } \\
\text { Ability }\end{array}$ & $\begin{array}{l}0.264 \\
(0)^{* * *}\end{array}$ & $\begin{array}{l}0.214 \\
(0)^{* * *}\end{array}$ & $\begin{array}{l}0.216 \\
(0)^{* * *}\end{array}$ & $\begin{array}{l}0.223 \\
(0)^{* * *}\end{array}$ & $\begin{array}{l}0.194 \\
(0)^{* * * *}\end{array}$ \\
\hline $\begin{array}{l}\text { Mother>s Cognitive } \\
\text { Ability }\end{array}$ & $\begin{array}{l}0.217 \\
(0)^{* * *}\end{array}$ & $\begin{array}{l}0.205 \\
(0)^{* * * *}\end{array}$ & $\begin{array}{l}0.205 \\
(0)^{* * * *}\end{array}$ & $\begin{array}{l}0.203 \\
(0)^{* * *}\end{array}$ & $\begin{array}{l}0.191 \\
(0)^{* * *}\end{array}$ \\
\hline $\begin{array}{l}\text { Father>s Height for } \\
\text { Age z-score }\end{array}$ & & $\begin{array}{c}0.002 \\
(0.597)\end{array}$ & $\begin{array}{c}0.002 \\
(0.514)\end{array}$ & $\begin{array}{l}0.002 \\
(0.42)\end{array}$ & $\begin{array}{c}0.003 \\
(0.399)\end{array}$ \\
\hline $\begin{array}{l}\text { Mother's Height for } \\
\text { Age z-score }\end{array}$ & & $\begin{array}{c}0.004 \\
(0.242)\end{array}$ & $\begin{array}{l}0.004 \\
(0.23)\end{array}$ & $\begin{array}{c}0.004 \\
(0.2)\end{array}$ & $\begin{array}{c}0.003 \\
(0.399)\end{array}$ \\
\hline Father>s Schooling & & $\begin{array}{c}0.006 \\
(0.004)^{* * * *}\end{array}$ & $\begin{array}{c}0.005 \\
(0.007)^{* * *}\end{array}$ & $\begin{array}{c}0.005 \\
(0.019)^{* *}\end{array}$ & $\begin{array}{c}0.004 \\
(0.054)^{*}\end{array}$ \\
\hline Mother>s Schooling & & $\begin{array}{c}0 \\
(0.901)\end{array}$ & $\begin{array}{c}0 \\
(0.874)\end{array}$ & $\begin{array}{l}-0.001 \\
(0.609)\end{array}$ & $\begin{array}{c}0.001 \\
(0.683)\end{array}$ \\
\hline Mother Works & & $\begin{array}{l}-0.011 \\
(0.502)\end{array}$ & $\begin{array}{l}-0.007 \\
(0.638)\end{array}$ & $\begin{array}{l}-0.006 \\
(0.724)\end{array}$ & $\begin{array}{l}-0.022 \\
(0.232)\end{array}$ \\
\hline $\begin{array}{l}\text { Log Household } \\
\text { Expenditure }\end{array}$ & & $\begin{array}{l}-0.001 \\
(0.905)\end{array}$ & $\begin{array}{c}0 \\
(0.997)\end{array}$ & $\begin{array}{l}-0.004 \\
(0.647)\end{array}$ & $\begin{array}{l}-0.002 \\
(0.827)\end{array}$ \\
\hline $\begin{array}{l}\text { Access to Private } \\
\text { Services }\end{array}$ & & $\begin{array}{c}0.062 \\
(0.005)^{* * * *}\end{array}$ & $\begin{array}{c}0.062 \\
(0.004)^{* * *}\end{array}$ & $\begin{array}{c}0.062 \\
(0.005)^{* * *}\end{array}$ & $\begin{array}{c}0.057 \\
(0.043)^{* *}\end{array}$ \\
\hline $\begin{array}{l}\text { Access to Public } \\
\text { Services }\end{array}$ & & $\begin{array}{l}-0.004 \\
(0.554)\end{array}$ & $\begin{array}{l}-0.004 \\
(0.572)\end{array}$ & $\begin{array}{l}-0.01 \\
(0.25)\end{array}$ & $\begin{array}{c}-0.018 \\
(0.079)^{*}\end{array}$ \\
\hline Number of Clinics & & & $\begin{array}{c}0.006 \\
(0.633)\end{array}$ & $\begin{array}{c}0.007 \\
(0.512)\end{array}$ & \\
\hline $\begin{array}{l}\text { Number of Primary } \\
\text { Schools }\end{array}$ & & & $\begin{array}{c}0.007 \\
(0.353)\end{array}$ & $\begin{array}{c}0.009 \\
(0.134)\end{array}$ & \\
\hline $\begin{array}{l}\text { Number of Middle } \\
\text { Schools }\end{array}$ & & & $\begin{array}{c}-0.02 \\
(0.135)\end{array}$ & $\begin{array}{l}-0.023 \\
(0.108)\end{array}$ & \\
\hline $\begin{array}{l}\text { Number of High } \\
\text { Schools }\end{array}$ & & & $\begin{array}{c}0.014 \\
(0.292)\end{array}$ & $\begin{array}{c}0.015 \\
(0.214)\end{array}$ & \\
\hline Rural & & & & $\begin{array}{c}-0.038 \\
(0.068)^{*}\end{array}$ & \\
\hline Log Total Population & & & & $\begin{array}{l}-0.002 \\
(0.393)\end{array}$ & \\
\hline $\begin{array}{l}\text { Negative of Local } \\
\text { Poverty Indicator }\end{array}$ & & & & $\begin{array}{c}0 \\
(0.976)\end{array}$ & \\
\hline $\begin{array}{l}\text { Local Public Policy } \\
\text { Indicator }\end{array}$ & & & & $\begin{array}{c}-0.01 \\
(0.034)^{* *}\end{array}$ & \\
\hline $\begin{array}{l}\text { Negative of Local } \\
\text { Marginalization }\end{array}$ & & & & $\begin{array}{c}0.025 \\
(0.007)^{* * *}\end{array}$ & \\
\hline $\begin{array}{l}\text { Local Economic } \\
\text { Activity Indicator }\end{array}$ & & & & $\begin{array}{l}-0.007 \\
(0.437)\end{array}$ & \\
\hline $\begin{array}{l}\text { Local Government } \\
\text { Improvement }\end{array}$ & & & & $\begin{array}{c}0 \\
(0.99)\end{array}$ & \\
\hline $\begin{array}{l}\text { Sum of Local Fixed } \\
\text { Effects }\end{array}$ & & & & & $\begin{array}{c}1 \\
(0)^{* * *}\end{array}$ \\
\hline \multicolumn{6}{|l|}{$\begin{array}{l}\text { Age Fixed Effects not } \\
\text { Reported }\end{array}$} \\
\hline Constant & $\begin{array}{l}0.398 \\
(0)^{* * *}\end{array}$ & $\begin{array}{c}0.414 \\
(0.001)^{* * *}\end{array}$ & $\begin{array}{l}0.401 \\
(0)^{* * *}\end{array}$ & $\begin{array}{l}0.487 \\
(0)^{* * *}\end{array}$ & $\begin{array}{l}0.447 \\
(0)^{* * *}\end{array}$ \\
\hline Observations & 1434 & 1434 & 1434 & 1434 & 1434 \\
\hline $\mathbf{F}$ & 23.81 & 20.54 & 20.7 & 16.1 & 8.5 \\
\hline Prob $>F$ & 0 & 0 & 0 & 0 & 0 \\
\hline R squared & 0.216 & 0.238 & 0.241 & 0.257 & 0.358 \\
\hline
\end{tabular}

Source: own elaboration. 
The CI for cognitive ability is shown in Table 2. The decomposition is shown in Tables 4.1 and 4.2. These tables show the percentage impact of each independent variable on the CI, together with the significance reported in the previous Tables 3.1 and 3.2. The reduction in inequity attributable to father's and mother's cognitive ability is approximately the same as before. In the case of 5 to 12 years old, the impact of mother's cognitive ability is much stronger than father's. This shows that her role is not described by our individual and local indicators. Again, when she works, this is associated with a reduction in inequity in cognitive ability associated also with a reduction in the levels of ability, as stated before.

As for local indicators, the rural indicator is associated with approximately one fourth of all cognitive inequity, including hereditary inequity. Note however that inequity cancellation is also present in the form of positive and negative contributors to inequity. Also relevant are the local economic activity, public policy and marginalization indicators, as well as local fixed effects in general.

The residual term shows how closely the decomposition adds up to $100 \%$ (except for numerical error; note also that age fixed effects have not been reported). Since socioeconomic status is close to being a linear combination of a subset of the dependent variables, it cannot be correlated with the error term, its components being fully represented on the right hand side.

The results show that inequities in local and regional economic indicators have strong associations with cognitive ability inequities.

\section{(iii) The cognitive transition}

Consider all municipalities with at least 9 daughters or 9 sons in the 13 to 18 year old sample. This age group is chosen because the same cognitive test is applied to parents and their children. Figures 1.1 and 1.2 (same scale, slightly shifted) show phase scatter plots for female and male intergenerational dynamics in cognitive ability, to which have been added the linear tendencies and a 45 degree line. These figures can be thought to portray a convergent long-term intergenerational transition in cognitive ability. At the present, mean cognitive ability is 0.60 for sons and daughters, while it is 0.475 for mothers and 0.498 for fathers. On the other hand, as they stand, the linear tendency and the 45 degree line intersect at approximately 0.84 in both the male and female cases. However, the estimates in Tables 3.1 and 3.2 shows that the tendency line should be rising as economic conditions improve. Thus steady state cognitive ability may be expected to rise even further. 
The Cognitive transition in MeXico: ECONOMIC GEOGRAPHY AND LOCAL GOVERNANCE IMPACTS

Such a transition in cognitive ability is consistent with the evidence for physioevolution presented by Fogel (op. cit.) and mentioned above.

Tabla 4.1

Concentration index decomposition for children's cognitive ability, ages 5 to 12

\begin{tabular}{|c|c|c|c|c|c|}
\hline Variable & 1 & 2 & 3 & 4 & 5 \\
\hline Gender & 0 & 0 & 0 & 0 & 0 \\
\hline Father's Cognitive Ability & $27.1^{* * *}$ & $24.5^{* * *}$ & $24.3^{* * *}$ & $24^{* * *}$ & $22.6^{* * *}$ \\
\hline Mother's Cognitive Ability & $54.7^{* * *}$ & $52.1^{* * *}$ & $51.8^{* * *}$ & $50.7^{* * *}$ & $48.4^{* * *}$ \\
\hline Father's Height for Age z-score & & -0.1 & 0 & -0.2 & -0.1 \\
\hline Mother's Height for Age z-score & & -1.8 & -1.9 & -1.9 & -2.4 \\
\hline Father's Schooling & & 1.9 & 1.2 & 0 & -0.5 \\
\hline Mother's Schooling & & 5.9 & 5.4 & 3.3 & 2.9 \\
\hline Mother Works & & $-8.3^{* * *}$ & $-8.5^{* * *}$ & $-8.4^{* * *}$ & $-9.2^{* * *}$ \\
\hline Log Household Expenditure & & 7.3 & 6.8 & 1.8 & 13.9 \\
\hline Access to Private Services & & $1.7^{* *}$ & $1.7^{* *}$ & $1.5^{*}$ & 1.3 \\
\hline Access to Public Services & & $24.3^{*}$ & $23.8^{*}$ & 20.2 & 21.8 \\
\hline Number of Clinics & & & 0.5 & 0.8 & \\
\hline Number of Primary Schools & & & $8.6^{*}$ & 3.6 & \\
\hline Number of Middle Schools & & & -9.8 & -6.4 & \\
\hline Number of High Schools & & & 4.3 & -0.4 & \\
\hline Rural & & & & $25.4^{* *}$ & \\
\hline Log Total Population & & & & 3.3 & \\
\hline Negative of Local Poverty Indicator & & & & 3.3 & \\
\hline Local Public Policy Indicator & & & & 0.1 & \\
\hline Negative of Local Marginalization & & & & 0.8 & \\
\hline Local Economic Activity Indicator & & & & $-11.2^{* *}$ & \\
\hline Local Government Improvement Indicator & & & & -0.5 & \\
\hline \multicolumn{6}{|l|}{ Age Fixed Effects not Reported } \\
\hline Sum of Local Fixed Effects & & & & & $9.2^{* * *}$ \\
\hline Residual & $27.8^{* * *}$ & $2^{* * *}$ & $1.5^{* * *}$ & $1.9^{* * *}$ & $2.1^{* * *}$ \\
\hline
\end{tabular}

Significance: ${ }^{*} 0.01,{ }^{* *} 0.05,{ }^{* * *} 0.01$

Source: own elaboration. 
Table 4.2

Concentration index decomposition for children's cognitive ability, ages 13 to 18

\begin{tabular}{|c|c|c|c|c|c|}
\hline Variable & 1 & 2 & 3 & 4 & 5 \\
\hline Gender & 0 & -0.1 & -0.1 & 0 & -0.2 \\
\hline Father's Cognitive Ability & $51.2^{* * *}$ & $41.6^{* * *}$ & $41.8^{\star * *}$ & $43.3^{* * *}$ & $37.6^{* * x}$ \\
\hline Mother's Cognitive Ability & $42.2^{* * *}$ & $39.8^{* * *}$ & $39.8^{\star * *}$ & $39.5^{\star * *}$ & $37.2^{* * x}$ \\
\hline Father's Height for Age z-score & & 1.9 & 2.4 & 3 & 3.3 \\
\hline Mother's Height for Age z-score & & 5.2 & 5.5 & 5.7 & 4.3 \\
\hline Father's Schooling & & $30.2^{* * *}$ & $28^{* * *}$ & $24.1^{\star *}$ & $23.4^{*}$ \\
\hline Mother's Schooling & & -1.6 & -2.1 & -6.5 & 6.4 \\
\hline Mother Works & & -2.6 & -1.8 & -1.4 & -5.3 \\
\hline Log Household Expenditure & & -2.7 & -0.1 & -8.8 & -4.7 \\
\hline Access to Private Services & & $2.9^{* * *}$ & $2.9^{* * *}$ & $2.9^{* * *}$ & $2.6^{* *}$ \\
\hline Access to Public Services & & -10 & -10.1 & -23.3 & $-43.2^{\star}$ \\
\hline Number of Clinics & & & 3 & 3.5 & \\
\hline Number of Primary Schools & & & 11.1 & 13.6 & \\
\hline Number of Middle Schools & & & -28.1 & -31.6 & \\
\hline Number of High Schools & & & 12.4 & 13.4 & \\
\hline Rural & & & & $27.7^{\star}$ & \\
\hline Log Total Population & & & & 0.1 & \\
\hline Negative of Local Poverty Indicator & & & & 0.1 & \\
\hline Local Public Policy Indicator & & & & $-8.4^{* *}$ & \\
\hline Negative of Local Marginalization & & & & $16.6^{* * *}$ & \\
\hline Local Economic Activity Indicator & & & & -5.4 & \\
\hline Local Government Improvement Indicator & & & & 0 & \\
\hline \multicolumn{6}{|l|}{ Age Fixed Effects not Reported } \\
\hline Sum of Local Fixed Effects & & & & & $43.7^{* * x}$ \\
\hline Residual & $2.6^{* * *}$ & $-8.1^{\star * *}$ & $-8.1^{\star * *}$ & $-8.1^{* * *}$ & $-8.4^{* * x}$ \\
\hline
\end{tabular}

Significance: ${ }^{\star} 0.1,{ }^{*} 0.05,{ }^{* * *} 0.01$

Source: own elaboration. 
The Cognitive transition in Mexico: ECONOMIC GEOGRAPHY AND LOCAL GOVERNANCE IMPACTS

\section{Figure 1}

\section{Cognitive ability dynamics in Mexico}

Average across selected municipalities represented in MxFLS survey, see text

Figure 1.1 Daughters 13 to 18 comparated to their mothers

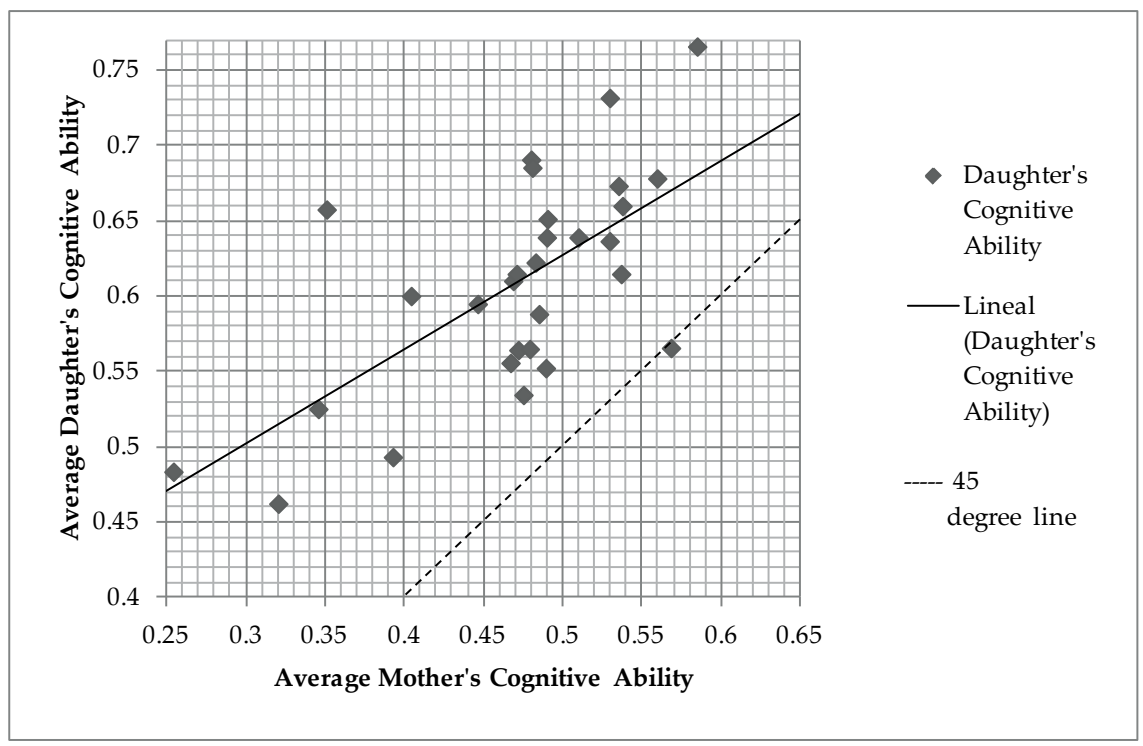

Figure 1.2 Sons 13 to 18 compared to their Fathers

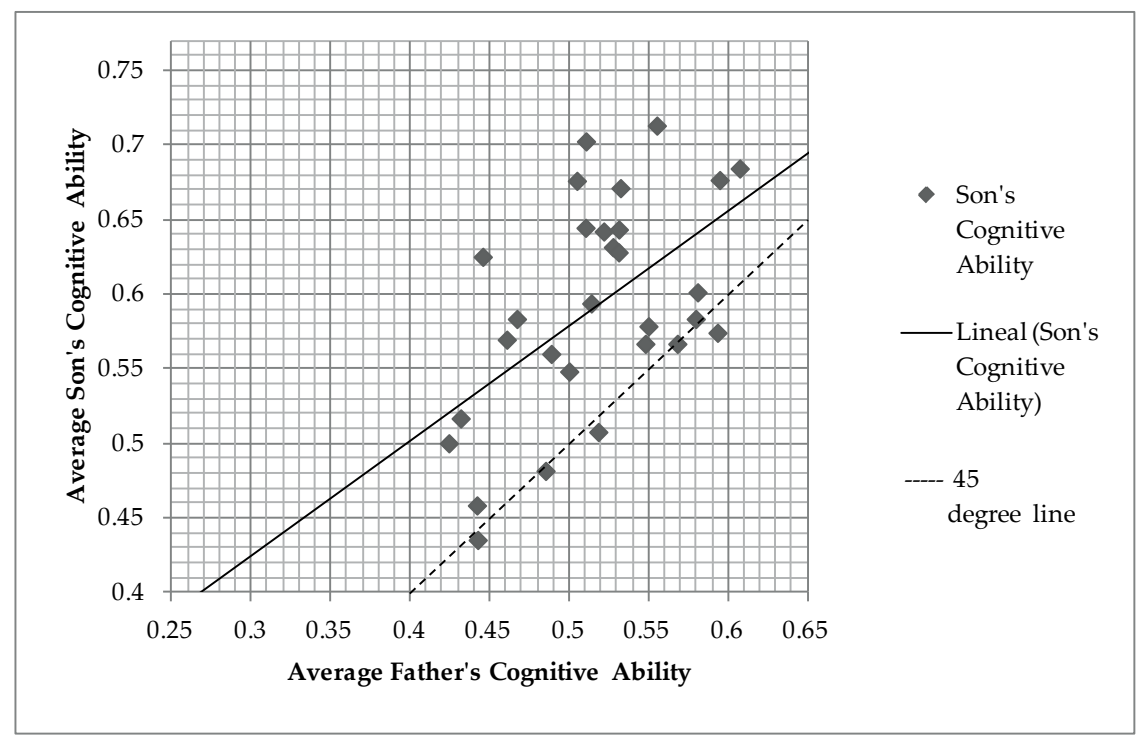

Source: own elaboration. 
DAVID MAYer-Foulkes

\section{Conclusion}

This article shows that both individual household variables, and local variables in economic geography and governance, are significantly associated with the formation of cognitive abilities. While father's and mother's cognitive ability may have genetic impacts on their children's cognitive ability, they also have sizeable impacts working through the access to individual and local goods. Mother not working and father's schooling are also positively associated with the acquisition of cognitive ability at different stages of childhood. So is the household's access to privately and publically provided services.

As for local characteristics, the basic economic geography distinction of rural versus urban is significantly associated with lower levels of cognitive capacity, accounting for about a fourth of total inequity. Also significant is local economic activity, with positive sign pointing towards development. As for governance, the presence of public policy programs, and a local indicator combining street quality with proportion of households with telephones, electricity and water are also significant. Local fixed effects per se are highly significant.

In addition, evidence is presented supporting the presence of a long-term, intergenerational transition converging towards higher levels of cognitive ability. At the current rate, this transition will take several generations to occur. However, this transition is taking place in a context of incentives and costs determined by local economic conditions and perspectives that tend to slow children's acquisition of cognitive ability. Poverty, uncertain incentives, migration costs, industrial scale effects, and deficiencies in transportation infrastructure translate into human capital investment shortfalls making current inequities persist.

The theoretical model shows that the dynamics of human development, as indicated by cognitive ability, are determined, not only by household assets, inherited or acquired, but that they also occur under the impact of economic geography and local governance. Inequities in cognitive ability, a crucial component in the intergenerational transmission of inequity, are shown by the estimate to depend on a broad spectrum of inequities in the provision of private, public and local goods that support family well-being as a whole.

This means that context matters above and beyond the individual endowments. The estimates show that inequity is associated with dimensions that are beyond the reach of the individual. This implies that exclusively 
market-based policies are not sufficient to foster human development, for these assume that decisions are in the hands of the individual. Instead, improvements in infrastructure and governance are necessary to relieve the restrictions and go beyond the externalities of economic geography and local governance.

To reduce human development inequities, of which cognitive ability is a direct indicator, public policies must address problems in the provision of private, public and local goods that support family well-being as a whole, in a manner tailored to local needs. The geographical and governance determinants we have mentioned are not subject to improvement through simplistic market policies. In this context, it is not so surprising that economic inequities are so persistent, and that they are so resistant to policies of market and macroeconomic reform. While exclusively marketbased policies may yield beneficial results, improving local governance so as to improve local economic performance and local ECD is essential to achieving higher rates of human development and poverty reduction. What is required is the implementation of much more sophisticated local governance and regional development policies that can make the critical economic investments -nowadays in the context of globalization- and also sustain ECD.

\section{References}

Arora, S. (2001), "Health Human Productivity and Long-Term Economic Growth", Journal of Economic History, vol. 61, no. 3, 699-749.

Baldwin, R., et al. (2003), Economic Geography and Public Policy, Princeton University Press, Princeton, N.J.

Behrman, R. and M. R. Rosenzweig (2002), “Does Increasing Women's

Schooling Raise the Schooling of the Next Generation?", American Economic Review, vol. 92, no. 1 (March), 323-334.

Black, S. E., P. J. Devereux, and K. G. Salvanes (2005), "Why the Apple Doesn't Fall Far: Understanding Intergenerational Transmission of Human Capital", American Economic Review, vol. 95, no. 1 (March), 437449.

Case, A., A. Fertig and C. Paxson (2003), "From Cradle to Grave?: The Lasting Impact of Childhood Health and Circumstance", NBER Working Paper 9788, Cambridge, MA: National Bureau of Economic Research. 
DAVID MAYer-Foulkes

Case, A., D. Lubotsky and C. Paxson (2002), "Economic Status and Health in Childhood: The Origins of the Gradient", American Economic Review, vol. 92, no. 5, 1308-1334.

Cervellati, M., and U. Sunde (2005), "Human Capital Formation, Life Expectancy and the Process of Economic Development", American Economic Review, vol. 95, no. 5, 1653-1672.

Fogel, R. W. and L. T. Wimmer (1992), “Early Indicators of Later Work Levels, Disease, and Death", NBER Historical Working Papers 38, National Bureau of Economic Research.

Fogel, R. W. (1994), “Economic Growth, Population Theory, and Physiology: The Bearing of Long-Term Processes on the Making of Economic Policy", American Economic Review, vol. 84, no. 3, 369-395.

Fogel, R. W. (2002), "Nutrition, Physiological Capital, and Economic Growth", Mimeo, Pan American Health Organization and Inter-American Development Bank. <http://www.paho.org/English/HDP/HDD/fogel. pdf $>$.

Harris J. and M. Todaro (1970), “Migration, Unemployment \& Development: A Two-Sector Analysis", American Economic Review, March 1970, vol. 60, no. $1,126-42$.

Heckman, J. and P. Carneiro (2003), "Human Capital Policy", NBER Working Paper 9495, Cambridge, MA: National Bureau of Economic Research.

Justino, P., J. Litchfield and L. Whitehead (2003), “The Impact of Inequality in Latin America", PRUS Working Papers 21, Poverty Research Unit at Sussex, University of Sussex.

Kolenikov, S. and G. Angeles (2004), "The Use of Discrete Data in Principal Component Analysis: Theory, Simulations, and Applications to Socioeconomic Indices", Working Paper of MEASURE/Evaluation project, No. WP04-85, Carolina Population Center, UNC.

Londoño, J. L. and M. Székely (2000), "Persistent Poverty and Excess Inequality: Latin America, 1970-1995", Journal of Applied Economics, vol. III, 93-134, May.

Mayer Foulkes, D., M. F. López Olivo and E. Serván Mori (2008), “Habilidades cognitivas: transmisión intergeneracional por niveles socioeconómicos", Estudios Económicos, vol. 23, no. 1, 129-156. Available at <http://estudioseconomicos.colmex.mx/vol23num1/129-156.pdf $>$.

Mayer-Foulkes, D. (2008a), “Economic Geography of Human Development: Stratified Growth in Bolivia, Brazil, Guatemala and Peru", Available at SSRN: <http://ssrn.com/abstract=1287952>. 
Mayer-Foulkes, D. (2008b), "The Human Development Trap in Mexico", World Development, vol. 36, no. 5, pp. 775-796.

Mayer-Foulkes, D. and E. Serván-Mori (2009), “Formación de la capacidad cognitiva en México: impactos económicos y de políticas públicas", Estudios Económicos, Número Extraordinario, (February), 83-122.

McKenzie, D. (2004), "Measuring Inequality with Asset Indicators", forthcoming, Journal of Population Economics.

Neisser, U. (1997), "Rising Scores on Intelligence Tests", American Scientist, vol. 85 , no. 5, 440-447.

Plug, E. (2004), “Estimating the Effect of Mother's Schooling on Children's Schooling Using a Sample of Adoptees", American Economic Review, vol. 94, no. 1 (March), 358-368.

Rosenzweig, Mark R. and Kenneth J. Wolpin (1986), “Evaluating the Effects of Optimally Distributed Public Programs", American Economic Review, vol. 76, no. 3 (June), 470-487.

Wagstaff, A., and E. van Doorslaer (2000), Measuring and Testing for Inequity in the Delivery of Health Care, Journal of Human Resources, vol. 35, no. 4, 716-733.

Wagstaff, A., et al. (2008), Analyzing Health Equity Using Household Survey Data: A Guide to Techniques and their Implementation, World Bank, Washington. 